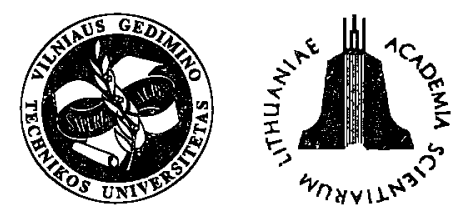

ISSN 1648-4142 TRANSPORT

http:/www.vtu.lt/english/editions

TRANSPORT - 2003, Vol XVIII, No 5, 202-208

\title{
THE INFLUENCE OF FUEL ADDITIVES SO-2E ON DIESEL ENGINE EXHAUST EMISSION
}

\author{
Gvidonas Labeckas, Stasys Slavinskas \\ Transport and Power Machinery Dept, Lithuanian University of Agriculture, \\ Studentu g. 15, Akademija, LT-4324 Kaunas region, Lithuania, Tel/Fax. (37) 752-311 \\ E-mail: gvidonas@info.lzuu.lt, sslavins@tech.lzuu.lt \\ Received 200303 02; accepted 20030901
}

\begin{abstract}
One of the methods that allows substantially to reduce exhaust smoke of diesel engines and avoid possible damage of the environment by harmful emissions is the usage of multipurpose fuel additives. The efficiency of new Estonian made fuel additives SO-2E, that have been introduced recently for the experts attention, was investigated in small heating boilers and low-powered ships. The purpose of this research is to determine the influence of fuel additives SO-2E on the performance of a high-speed direct injection diesel engine in order to evaluate some of quantitative composition changes of the exhaust gases especially environmentally harmful nitrogen oxides, carbon monoxides and smoke emissions.

Bench tests have been performed on the four-stroke, four-cylinder, water-cooled direct injection diesel engine D-243 with splash volume $V_{l}=4,75 \mathrm{dm}^{3}$ and compression ratio $\varepsilon=16: 1$. Test results show that the application of diesel fuel additives SO-2E in proportion 1:500 (0,2 \% by volume) at engine rated power reduces nitrogen monoxides $N O$ and common $\mathrm{NO}_{x}$ emission by 11,54 and 9,64 \% respectively, however the amount of $\mathrm{NO}_{2}$ in totally diminished background of nitrogen oxides increases by 7,39\%. On the other hand, when running the engine at moderate (bmpe $=0,35 \mathrm{MPa}$ ) load, the fuel additives reduce emissions of all nitrogen components - NO by $16,1 \%, N O_{2}$ by $11,8 \%$ and $N O_{x}$ by $15,7 \%$. The influence of fuel additives on the amount of carbon monoxides in the exhausts seems to be more complicated. At engine rated speed/power fuel additives increase $C O$ emission by $12,5 \%$, but as soon as engine load increases and revolution frequency drops down to the maximal torque area $n=1600-1800 \mathrm{~min}^{-1}$, they reduce the amount of $\mathrm{CO}$ in the exhaust gases on the average $20-28 \%$. It is important to notice that the changes in the smoke emission remain in close association with $\mathrm{CO}$ emissions. At certain revolution frequencies and moderate load the fuel additives SO-2E lead to noticeable reduction of the exhaust smoke, however at engine rated power and speed the smoke emission is obtained approximately $5-10 \%$ higher. In spite of dissimilar influence of the fuel additives SO-2E on the quantities of $C O$ produced and exhaust smoke it would be worth to apply them in high-speed DI diesel engines in order to reduce nitrogen oxides $N O_{x}$ emission.
\end{abstract}

Keywords: diesel engine, fuel additives, emission, nitrogen oxides, carbon oxides, smoke.

\section{Introduction}

The global atmospheric changes that continue to be under investigation of many world researchers are closely related to intensive industrial and agricultural activity leading to an unallowable high level of environmental and atmospheric pollution. Up to $70 \%$ of air pollution falls to permanently growing number of automobiles, tractors and mobile agricultural technique. Air pollution remains especially a big problem in the most developed countries. Polluted air has a negative impact on plants, animals and people health, damages historical buildings and statues.

The main part of air pollution depends on internal combustion engines running on petroleum gas. Today, however, a big concern arises in relation to growing oil product prices and a rapidly increased number of more economical diesel engines that may become in the nearest future the main air pollution sources. In relation to a permanently growing number of diesel engines in Lithuania and neighboring countries and also the application of more strict emission requirements in $\mathrm{EU}$ the air pollution problem remains especially important.

Different from petroleum gas (Otto) engines which main pollutants consist of carbon monoxides $\mathrm{CO}$, hydrocarbons $\mathrm{HC}$ and aldehydes, diesel engines exhaust basically environmentally harmful nitrogen oxides $\mathrm{NO}_{\mathrm{x}}$ and carbon monoxides $\mathrm{CO}$, particle matters (PM) and soot.

\section{The Analysis of the Emissions and References}

The analysis of a nitrogen oxides formation process can be made on the basis of the world-known chain 
reactions mechanism that is developed by Zeldovich [1]. In combustion reactions the active action is taken by the free atoms of nitrogen and oxygen build up at high temperatures when a dissociation process of these elements is going on:

$$
\begin{aligned}
& O+N_{2} \Leftrightarrow N O+N, \\
& N+O_{2} \Leftrightarrow N O+O .
\end{aligned}
$$

The velocity of chain reactions basically depends on the first endothermic reaction that requires a lot of energy $(316,1 \mathrm{~kJ} / \mathrm{k}-\mathrm{mol})$. The oxides of nitrogen emerge in the engine cylinder due to very fast changes of gas pressure and temperature. These factors taken together, including the peak temperatures of the gases, make a decisive role on the reaction processes. When gas temperature exceeds $2500 \mathrm{~K}$, the nitrogen oxides relaxation time strikes only $\tau \leq 5 \cdot 10^{-3} s$ that is far behind in comparison with the duration of all the cycle. For this reason when oxidation reactions take place the combustion gases are in the state of thermodynamic equilibrium. Subsequently, due to rapid gas temperature drop during the extension process, the relaxation period of nitrogen oxides becomes longer. When gas temperature falls down to $<2300 \mathrm{~K}$, relaxation period becomes longer than $10^{-1} \mathrm{~s}$ and noticeably exceeds the common duration of the cycle. Due to rapid pressure and temperature reduction thermodynamic equilibrium of the gases during reactions becomes violated and so-called "hardening" phenomenon of the gases occurs. It means, when the temperature of the gases goes down to about $\sim 2300 \mathrm{~K}$, the concentration of $N O$ remains on the equilibrium mode level. Therefore the concentration of nitrogen monoxides NO depends also on gas cooling rate in the expansion process.

From this point of view John Deere 4276T fourcylinder, four-stroke, turbocharged DI diesel engine testing results are interesting [2]. Engine was fuelled with two different biodiesel fuels, one of which had been deliberately oxidized, and with their $20 \%$ blends with diesel fuel. In case of biodiesel the heating value of the combustible mixture and the flame temperatures are slightly lower, but the emission of nitrogen oxides is higher. Therefore, the authors came to the conclusion that the flame temperature changes alone cannot adequately explain the higher levels of $N O_{x}$ observed with biodiesel.

Higher emission levels of nitrogen oxides may be related to more advanced start of combustion before TDC due to a higher cetane number of biofuel, causing a shorter auto-ignition delay and conforming to its earlier actual injection timing [2]. The investigation results of four cylinder Daimler Chrysler engine OM 904 LA (125 kW) on four modes of the 13-mode test ECE R49 [3] also indicate a tendency to slightly higher $N O x$ emissions with RME versus Swedish low sulphur fossil fuel. Such approach in evaluation of NOx emission causes seems to be in good agreement with extended Zeldovich thermal nitrogen oxides mechanism [1] because the factors mentioned above influence the flame temperatures and cooling rate of the gases in the expansion stroke.

The study of ethylene glycol monoacetate $\left(\mathrm{C}_{4} \mathrm{H}_{8} \mathrm{O}_{3}\right)$ as oxygenating additive mixed with diesel fuel (ASTM № 2D) in various proportions was carried out on a fourcylinder arranged in-line, four-stroke, direct-injection, naturally air aspirated marine diesel engine UMBDI (model from the Isuzu Co. Japan) [4]. Ethylene glycol monoacetate is oxygen-rich fuel with considerably lower heating value $(25,91 \mathrm{MJ} / \mathrm{kg})$ in comparison with diesel fuel $(42,5 \mathrm{MJ} / \mathrm{kg}$ ). The addition of these additives (up to $10 \%$ ) in the diesel fuel caused an increase in brake specific fuel consumption $(b s f c)$, lowered exhaust gas temperatures and decreased NOx emissions. According to the author's opinion [4], it happened because an oxygenating additive increased air-fuel equivalence ratio, shortened the auto-ignition delay and lowered the amount of premixed fuel. These factors lowered peak burning temperatures and as a result decreased harmful $N O x$ emission.

In accordance with [5], the nitrogen oxides built up under high temperatures (over $2000 \mathrm{~K}$ ) behind the front borders of the flame when free nitrogen atoms in complicated chain reactions unite with the excess of oxygen that the combustion chamber contains. Content of $N O_{x}$ in the exhaust gases depends basically on the maximal temperature of the process because this reaction is endothermic and does not associate directly with the mixture combustion processes.

Whereas the smoke formation process occurs mainly in the local zones supersaturated by the fuel where pyrolisis of the hydrocarbons is going on in accordance with a complicated multi-stage mechanism of fractioning and decomposing of the fuel molecules. As a result, the exhaust smoke of diesel engines depends basically on the chemical structure of the fuel, $i$. e. on the amount of aromatic hydrocarbons in the fuel content and its cetane number, on diffusion processes that follow in combustion chamber, multiplex mechanism of soot particles formation and its combustion reactions velocity [5].

Recently one of the possible methods of diesel engines emission reduction is the application of multipurpose fuel additives. The broad scale fuel additives improve the complete combustion of the mixture and reduce the amount of harmful emissions. Some of the multipurpose fuel additives, e.g. Swedish MARISOL FT, at engine D-240 moderate load suppress little concentration of nitrogen oxides in the exhausts, likewise at engine rated power reduce the effective specific fuel consumption by $2,2 \%$ [6]. The application of these additives leads also to declining of exhaust temperature by $20-40^{\circ} \mathrm{C}$.

A couple of years ago new fuel additives SO-2E appeared and they were produced in neighbouring Esto- 
nia. The effectiveness of these additives has been investigated in small heating boilers and low-powered ships engines fuelled with the experimental shale oil that was produced from the local oil shale resources. However, the influence of additives SO-2E on the exhaust gas toxicity and smoke of a high-speed diesel engine that runs on commercial diesel fuel has not been tested yet.

\section{Purpose of the Research}

The purpose of this research is to determine the influence of fuel additives SO-2E on the performance of a high-speed direct injection diesel engine, to evaluate the quantitative composition changes of the exhaust gases especially harmful nitrogen oxides $\mathrm{NO}, \mathrm{NO}_{2}, \mathrm{NO}_{X}$, carbon monoxides $\mathrm{CO}$ and smoke emissions.

\section{Research Objects, Apparatus and Methods}

A completely commissioned D-243 four-cylinder, four-stroke, natural aspirated DI diesel engine with a bore of $110 \mathrm{~mm}$, a stroke of $125 \mathrm{~mm}$, displacement of 4,75 1 , rated brake power $59 \mathrm{~kW}(80 \mathrm{hp})$ and compression ratio of $16: 1$ was connected to a $110 \mathrm{~kW}(150 \mathrm{hp})$ model KS56-4 AC (Czech Republic) electrical dynamometer. The fuel was delivered by the in-line model 4UTNM (NZTA) fuel-injection pump through five hole injection units into a toroidal type combustion chamber in a piston head. The fuel injection pump was adjusted for the initial fuel delivery start at $25^{\circ}$ before top dead centre (TDC). The initial needle opening pressure for all injectors was equal to $17,5 \pm 0,5 \mathrm{MPa}$.

The diesel engine was fuelled with the F category winter diesel fuel that meets the quality requirement of LST EN 590:2000 standard. An electronic scale VLK500 and a stopwatch were used to determine mass fuel flow. Volumetric air consumption of the engine was measured with the rotor type gas counter RG-400-1-1,5.

The fuel additives SO-2E are produced at Estonian joint-company Viru Ölitööstus AS in Kohtla-Järve. Additives look like stiff enough, viscous, water free, poisonous material with a very specific odour and hardly soluble in diesel fuel black-brown liquid (Table). Additives $\mathrm{SO}-2 \mathrm{E}$ are a little heavier than water, they contain about 5,3\% phenol, 0,53\% sulphur and 0,04\% ash. Alkali component of the phenol reduces acidity of diesel fuel, assists to wash out and eliminate tar deposits. The fuel additives SO-2E were mixed with diesel fuel in proportion 1:500 (0,2\%) by volume.

Load characteristics were taken at steady engine performance modes and constant crankshaft revolution frequencies $n=1400,1600,1800,2000$ and $2200 \mathrm{~min}^{-1}$. At these five revolutions the exhaust gas emission was measured at 6-7 variable load-points as the latter gradually has been changed from the minimal $20 \%$ up to the maxi-
The basic properties of fuel additives SO-2E

\begin{tabular}{|l|c|}
\hline Density at $\left(20^{\circ} \mathrm{C}\right) \mathrm{g} / \mathrm{cm}^{3}$ & 1,030 \\
\hline Phenol \% & 5,3 \\
\hline Pour point oC & -4 \\
\hline Acidity mg KOH/g & 0,44 \\
\hline Sulphur \% & 0,53 \\
\hline Ash \% & 0,04 \\
\hline Water \% & 0 \\
\hline
\end{tabular}

mal $110 \%$ of its rated value.

The revolution frequency of crankshaft was measured with a universal ferrite-dynamic stand tachometer TSFU-1 and its counter ITE-1 connected to the meter sensor DTE-2 with accuracy of $\pm 0,2 \%$.

The amounts of carbon monoxides $\mathrm{CO}(\mathrm{ppm})$, dioxides $\mathrm{CO}_{2}(\%)$, nitrogen monoxides $\mathrm{NO}(\mathrm{ppm})$ and dioxides $\mathrm{NO}_{2}$ (ppm) in the exhaust gases were measured with Testo 33 (Germany) gas analyser. This device enabled us also to get ideas about air-fuel equivalence ratios $\lambda(\alpha)$ for various combustible mixtures. The total emission of nitrogen oxides $\mathrm{NO}_{\mathrm{x}}$ was determined as a sum of $\mathrm{NO}$ and $\mathrm{NO}_{2}$ components.

Afterwards the carbon monoxides $\mathrm{CO}(\%$ vol), dioxides $\mathrm{CO}_{2}$ (\% vol) and hydrocarbons $\mathrm{HC}$ (ppm vol) emissions as well as the amount of free oxygen $\mathrm{O}_{2}$ (\% vol) in the exhaust gases were additionally checked with Italic production device TECHNOTEST Infrared Multigas TANK, mode 488 OIML automobile gas analyser.

Smoke opacity D (\%) of the exhaust gases was measured with Bosch device RTT 100/RTT 110 in $1-100 \%$ scale with $\pm 0,1 \%$ accuracy and its temperature in the exhaust manifold was measured with chromel-alumel thermocouple TChK-400U connected to galvanometer MKD-50M.

\section{The Research Results}

The application of fuel additives SO-2E does not influence noticeably the engine D-243 effective parameters. At engine revolution frequencies $n=1600-1800 \mathrm{~min}^{-1}$ the consumption of the fuel, that was intentionally pre-treated with additives, is obtained a little (2-3\%) higher, but at other running speeds $\left(1400,2000\right.$ and $\left.2200 \mathrm{~min}^{-1}\right)$ effective specific fuel consumption throughout wide loads alternation range remains almost unchanged. The usage of fuel additives does not have any noticeable influence on the air-fuel equivalence ratio $\alpha(\lambda)$ as well, - that gradually declines from 5,75 to about 1,65 when engine load increases to its maximal level.

However, having filled additives SO-2E into diesel fuel, some quantitative composition changes of the harm- 
ful components occur in the exhaust gases. It becomes evident that diesel fuel that was pre-conditioned with additives creates much less amount of total nitrogen oxides $\mathrm{NO}_{\mathrm{x}}$ in the combustion process. It is very important because $\mathrm{NO}_{\mathrm{x}}$ has an especially harmful impact on the environment and people health. At moderate load (bmep $\leq 0,2 \mathrm{MPa}$ ) the influence of fuel additives SO-2E on total nitrogen oxides $\mathrm{NO}_{\mathrm{x}}$ emission (ppm) is negligible. But as far as the engine load and the amount of the fuel being injected per cycle increases, the maximal combustion temperature goes up. In such circumstances the formation of nitrogen oxides obtains more stimulus [1,5]. When absolute $\mathrm{NO}_{\mathrm{x}}$ amounts in the exhausts become higher the positive effect of the fuel additives SO-2E also increases.

As one can notice on the graphs (Fig 1) in case of engine performance at brake mean effective pressure (bmep) higher than $0,2-0,3 \mathrm{MPa}$, the total emission of nitrogen oxides when engine is run on pre-treated fuel throughout all revolution frequencies variation range is reduced by $75-125 \mathrm{ppm}(4,0-6,5 \%)$. Especially effectively nitrogen oxides are being suppressed when engine runs on its maximal load and rated $2200 \mathrm{~min}^{-1}$ speed, $\mathrm{NO}_{\mathrm{x}}$ emission reduces by $230-280 \mathrm{ppm}$ or about $10 \%$. At engine maximal torque regime and $100 \%$ load $(n=$ $\left.1600 \mathrm{~min}^{-1}\right)$ or in overload zone $\left(n=1400 \mathrm{~min}^{-1}\right)$ fuel additives SO-2E reduce the emission of nitrogen oxides correspondingly by 7,5 and $6,0 \%$. In other words, when running the engine with the fuel additives $\mathrm{SO}-2 \mathrm{E}$ the same nitrogen oxides emission level (2000 ppm) can be produced at about $25 \%$ higher brake power developed.

The analysis of the data given on the graphs (Fig 1) leads to the conclusion that the total emission of nitrogen oxides more likely depends on engine load (bmep), it means on quantitative/structural changes of combustible mixture prepared (air-fuel equivalence ratio $\alpha$ drops from 5,75 to 1,65 ) and increased temperatures in the chamber than on the crankshaft revolution frequency or

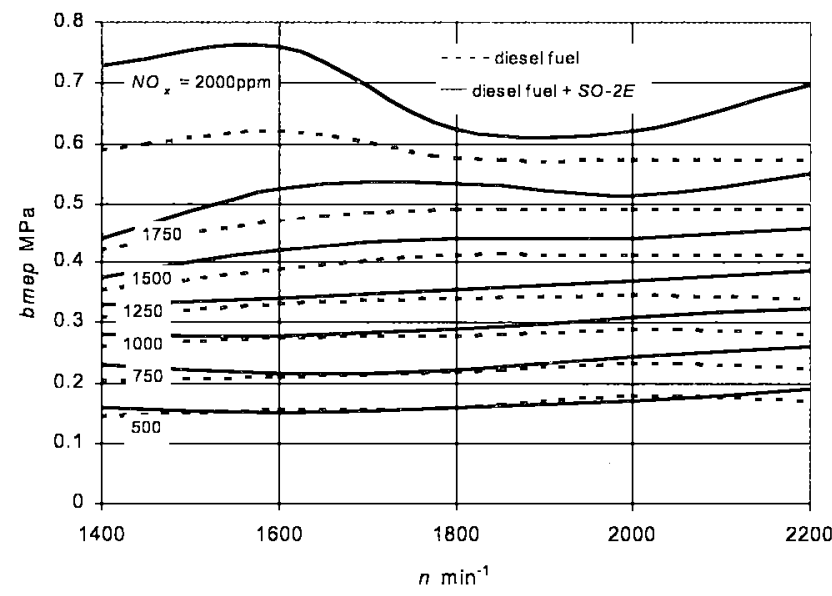

Fig 1. Dependency of common nitrogen oxides $\mathrm{NO}_{\mathrm{x}}$ emission on engine revolution frequency $(n)$ and load (bmep) gas turbulence intensity. For this reason the fuel additives have more potentiality to reduce $\mathrm{NO}_{x}$ at engine higher load. However, as one can notice on the graphs of Fig 2 a-d, in case of additives application load dependent influence on specific nitrogen compounds $\mathrm{NO}, \mathrm{NO}_{2}$ and $\mathrm{NO}_{\mathrm{x}}$ formation at various engine revolution frequencies is different. The positive effect of fuel additives SO$2 \mathrm{E}$ on nitrogen oxides reduction can be related to lower maximal combustion temperatures. In accordance with measurement results, due to additives application temperature of the exhaust gases at engine rated speed and its maximal load is reduced from 485 to $445^{\circ} \mathrm{C}$ (by 40 ${ }^{\circ} \mathrm{C}$ ). As far as temperature of the gases decreases it definitely reduces the amount of NO emission and provokes some of $\mathrm{NO}_{2}$ rising tendency, however the latter (184 ppm) makes up only the tenth part of nitrogen monoxides (1752 ppm) emission. So, at high temperatures the influence of fuel additives on $\mathrm{NO}$ and $\mathrm{NO}_{2}$ emission seems to be contrary. On the other hand, at reduced engine load, higher air-fuel equivalence ratio and lower temperature of the gases, the total $\mathrm{NO}_{\mathrm{x}}$ emission is lower and the effect due to fuel additives usage on all nitrogen oxide components remains unambiguous.

In more detail the influence of fuel additives SO-2E on nitrogen monoxides $\mathrm{NO}$, dioxides $\mathrm{NO}_{2}$ and total $\mathrm{NO}_{x}$ emissions when engine D-243 works at various loads and different revolution frequencies $n=1600-2200 \mathrm{~min}^{-1}$ one can evaluate having made the analysis of graphs in Fig 2, a-d. They reflect the percentage changes of nitrogen oxides at three different load regimes: 1) $b m e p=0,35 \mathrm{MPa}$; 2) $b m e p=0,50 \mathrm{MPa}$ and 3) $b m e p=0,65 \mathrm{MPa}$ in comparison with their base-rates when the engine is fuelled with diesel fuel without any additives given in ppm above each column of components.

The analysis of graphs points out that the usage of fuel additives really reduces $\mathrm{NO}$ and total $\mathrm{NO}_{\mathrm{x}}$ emission. As we pointed earlier (Fig 1), the influence of additives is the most noticeable at moderate (Fig 2, a-b.) and maximal (Fig 2, c-d) loads, - $\mathrm{NO}_{\mathrm{x}}$ reduces correspondingly by $7,7-6,0$ and $9,6-10,2 \%$. It is important to underline that total $\mathrm{NO}_{\mathrm{x}}$ amounts reduce namely due to suppression of the most harmful for the environment and people health nitrogen monoxides $\mathrm{NO}$ as the emission $\mathrm{NO}_{2}$ at engine maximal load throughout all the revolution frequencies variation range remains slightly higher. When engine runs at the maximal load and speeds e.g. $n$ $=1800$ and $2000 \mathrm{~min}^{-1} \mathrm{NO}_{2}$ emission is higher correspondingly by 6,2 and $7,4 \%$ than during its run without additives. Although $\mathrm{NO}_{2}$ emissions expressed in ppm (Fig 2) are not very high.

At moderate load (bmep $=0,35 \mathrm{MPa}$ ) the biggest $\mathrm{NO}_{\mathrm{x}}$ reduction, expressed in percentage $(15,7 \%)$, is obtained at engine rated speed $n=2200 \mathrm{~min}^{-1}$. It is worth to notice that in this particular case the reduction of total $\mathrm{NO}_{\mathrm{x}}$ emission was achieved due to a lower level of both 

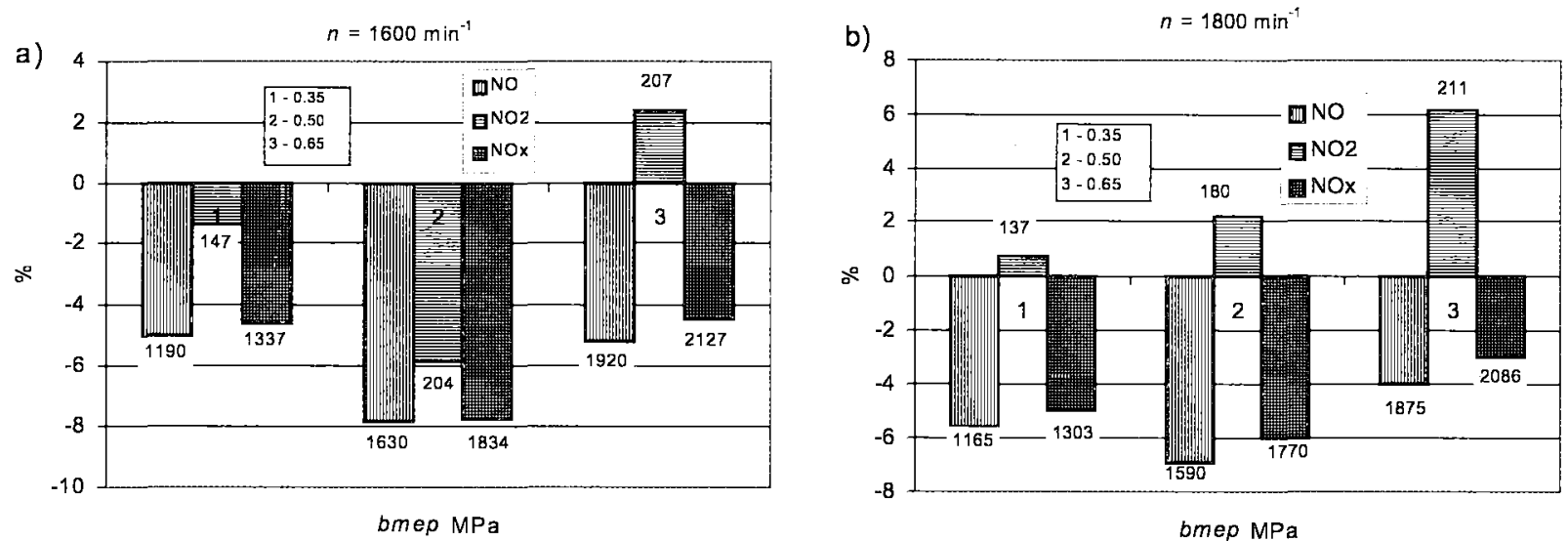

bmep MPa
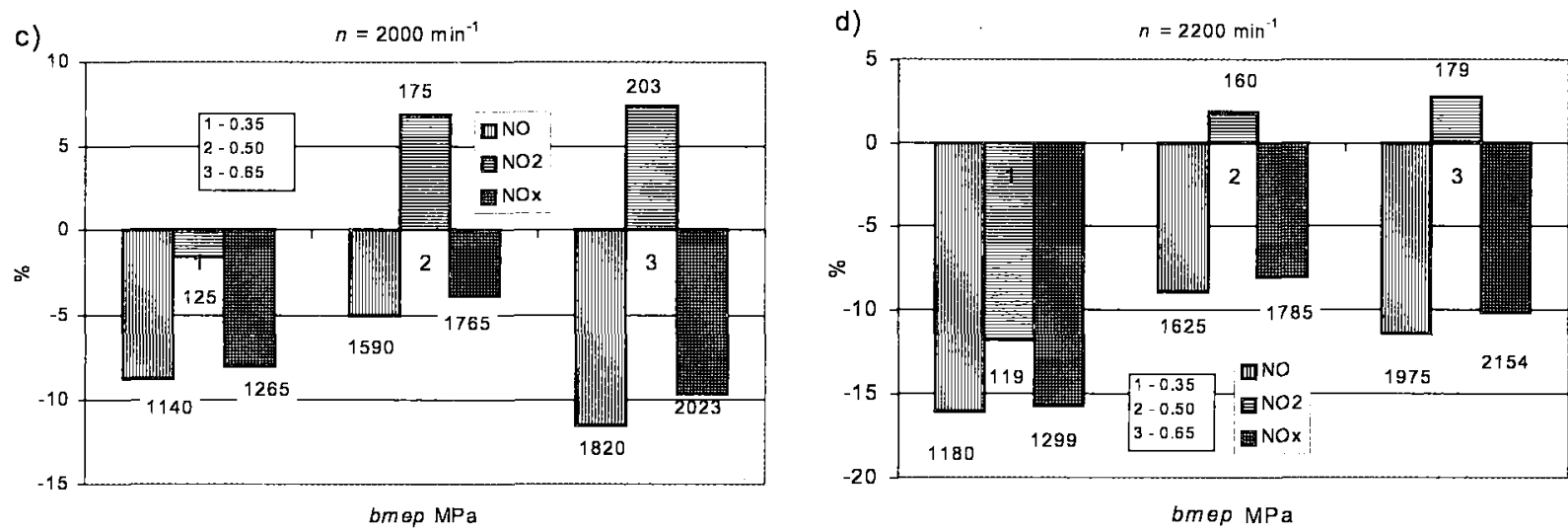

Fig 2. Influence of fuel additives $\mathrm{SO}-2 \mathrm{E}$ on nitrogen oxides $\mathrm{NO}, \mathrm{NO}_{2}$ and $\mathrm{NO}_{\mathrm{x}}$ emission when running the engine at different loads $b$ mpe $=0,35 ; 0,50$ and $0,65 \mathrm{MPa}$ and various revolution frequencies $n=1600$ (a); 1800 (b); 2000 (c) and 2200 (d) min ${ }^{-1}$

toxic components - NO (16,1\%) and $\mathrm{NO}_{2}(11,8 \%)$ (the first columns group of Fig 2, d). At other revolutions $n=$ 1600,1800 and $2000 \mathrm{~min}^{-1}$ and low-level loads fuel additives SO-2E noticeably (by 5,$0 ; 5,6$ and $8,8 \%$ ) reduce $\mathrm{NO}$ and slightly $(1,4 ;+0,7$ and $1,6 \%)-\mathrm{NO}_{2}$ emission (Fig 2, a-c). As a result the total nitrogen oxides emission reduces correspondingly by 5,$0 ; 5,6$ and $8,8 \%$. It should be pointed, however, that when engine load increases, one can notice clear $\mathrm{NO}_{2}$ rising tendencies. When load goes up to $b m e p=0,65 \mathrm{MPa}$ fuel additives stimulate $\mathrm{NO}_{2}$ emission by $6,2 \%\left(n=1800 \mathrm{~min}^{-1}\right)$ and $7,4 \%$ $\left(n=2000 \mathrm{~min}^{-1}\right)$. Dissimilar effect of fuel additives on $\mathrm{NO}$ and $\mathrm{NO}_{2}$ emission may be related to a different formation mechanism of considered components that becomes more evident at increased engine load and consequently higher temperatures of the combustion process. Whereas engine revolution frequency, hence combustible mixture turbulence intensity, has considerably less influence on total $\mathrm{NO}_{\mathrm{x}}$ and its components emission.

Carbon monoxides can be formed in the local places of the chamber where the access to oxygen necessary for complete mixture combustion is strongly limited. At idle or small load it is rather difficult to inject accurately very small portions of fuel and to distribute it equally through- out the combustion chamber volume. Under such circumstances even at satisfactory excess of the air along the fuel spouts propagation pathways and in some particular areas of chamber the lack of oxygen needed for complete combustion may occur. On the other hand, at the increased fuel delivery per cycles up to the engine load approaching the smoke limit zone, the emission of carbon monoxides due to the lack of oxygen is unavoidable. These carbon atoms presented in the fuel content and not completely burnt out increase $\mathrm{CO}$ emission and witnesses about less effective fuel energy conversion to heat. This may be is the answer why CO emission graphlines alternation along engine revolution frequencies and its brake mean effective pressure coordinates (Fig 3) seems so similar to the known brake specific fuel consumption maps.

During engine performance at a small load additives SO-2E do not have any clear influence on carbon monoxides emission. At brake mean effective pressures less than $0,25 \mathrm{MPa}$ and certain revolution frequencies ( $n$ $=1600 \mathrm{~min}^{-1}$ ) fuel additives can even provoke (up to 20 $\%) \mathrm{CO}$ emission. When engine runs on its maximal load the influence of fuel additives becomes more evident. One can see in the graphs of Fig 3, when engine runs on 


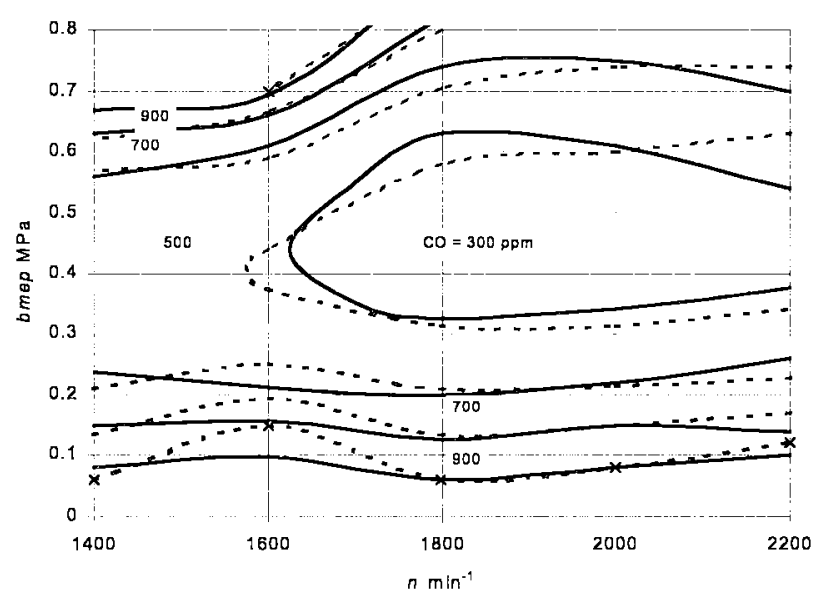

Fig 3. Dependency of carbon monoxides CO emission on engine revolution frequency $(n)$ and load (bmep)

frequency $n=1800 \mathrm{~min}^{-1}$ fuel additives reduce CO emission on the average by $20-28 \%$. At slightly increased revolutions $2000 \mathrm{~min}^{-1}$ the effect of fuel additives becomes minor. When engine runs on its rated speed $n=$ $2200 \mathrm{~min}^{-1} \mathrm{CO}$ emission due to the usage of pre-treated fuel increases by $12,5 \%$ and more. Such variable impact of additives $\mathrm{SO}-2 \mathrm{E}$ on $\mathrm{CO}$ and $\mathrm{NO}_{\mathrm{x}}$ emissions witnesses again about different carbon monoxides and nitrogen oxides derivation mechanism [5].

The exhaust smoke when engine runs at moderate load (bmep $=0,45 \mathrm{MPa}$ ) does not exceed $10-15 \%$. In some circumstances, e.g. $n=1400$ and $2000 \mathrm{~min}^{-1}$, the smoke reduction due to additives usage is noticeable enough (Fig 4). Although at more increased loads when engine exhaust smoke reaches approximately $50 \%$ level, positive additives influence gradually goes down till completely diminishes. So, from the smoke point of view engine emissions during the performance with the fuel additives and without them differ marginally. At engine maximal torque or at its rated speed fuel additives in-

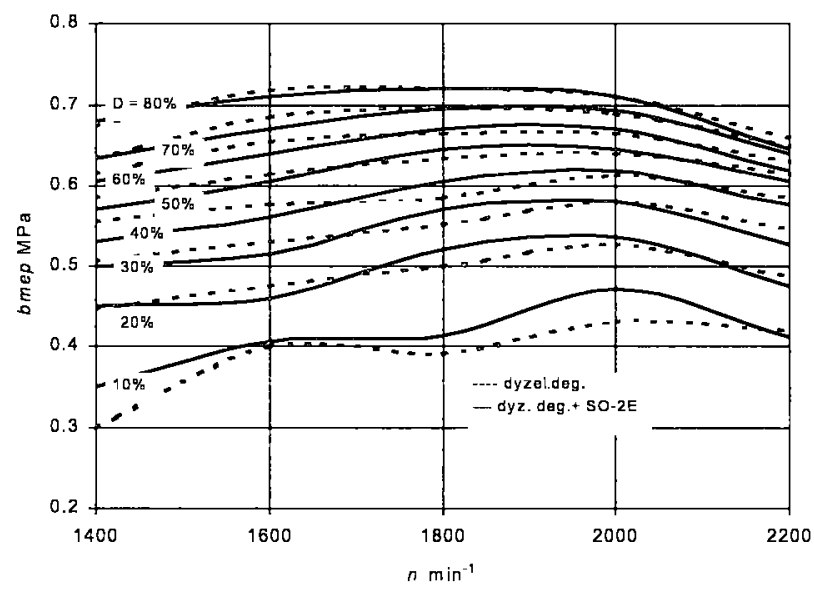

Fig 4. Dependency of smoke $D$ emission of exhaust gases on engine revolution frequency $(n)$ and load (bmep) crease the smoke emission approximately by $5-10 \%$. A little elevated smoke level remains here in good agreement with obtained higher $\mathrm{CO}$ and lower $\mathrm{NO}_{\mathrm{x}}$ emissions.

Regarding the effect of fuel additives SO-2E on $\mathrm{HC}$ emissions no general tendency was found. But in any case it is clearly verified that there is no rise of $\mathrm{HC}$ emission with the use of the additives. The amounts of hydrocarbons in the exhausts remained minor in the whole, they did not exceed $20 \mathrm{ppm}$ and with engine load and speed changed only a little. It may mean that the testing conditions and engine technical state were all-right.

\section{Conclusions}

1. The total emission of nitrogen oxides depends mostly on engine load that is on gas temperature in the cylinder, - rise of brake mean effective pressure from 0,35 until $0,65 \mathrm{MPa}$ throughout tested revolution frequencies range $n=1400-2200 \mathrm{~min}^{-1}$ leads to the increase of $\mathrm{NO}_{\mathrm{x}}$ amounts in the exhaust gases on the average 1,6 times. The influence of engine revolution frequency and the intensity of gas turbulence on $\mathrm{NO}_{x}$ emission is negligible.

2. The fuel additives $\mathrm{SO}-2 \mathrm{E}$ reduce the amount of nitrogen oxides in the exhaust gases efficiently enough. At engine rated speed nitrogen monoxides $\mathrm{NO}$ and the total $\mathrm{NO}_{\mathrm{x}}$ emission is reduced correspondingly by 11,54 and $9,64 \%$, but the amount of $\mathrm{NO}_{2}$ in totally diminished background of nitrogen oxides increases by $7.39 \%$. However, when engine runs at moderate (bmpe $=0.35 \mathrm{MPa}$ ) load, the fuel additives reduce the emissions of all nitrogen components - NO by $16,1 \%, \mathrm{NO}_{2}$ by $11,8 \%$ and $\mathrm{NO}_{\mathrm{x}}$ by $15,7 \%$.

3 . The influence of fuel additives on the amount of carbon monoxides in the exhausts seems to be even more complicated. At engine rated speed/power fuel additives increase $\mathrm{CO}$ emission by $12,5 \%$, but as soon as engine load increases and revolution frequency drops down to the maximal torque area $n=1600-1800 \mathrm{~min}^{-1}$, they reduce the amount of $\mathrm{CO}$ in the exhaust gases on the average $20-28 \%$.

4. It is important to notice that changes in the smoke emission remain in close association with $\mathrm{CO}$ emissions. At certain revolution frequencies and moderate load, the fuel additives SO-2E lead to noticeable reduction of the exhaust smoke, however at engine rated power and speed the smoke emission is obtained approximately $5-10 \%$ higher.

5. In spite of different influence of the fuel additives SO-2E on the quantities of produced $\mathrm{CO}$ and exhausted smoke it would be worth to apply it in high-speed DI diesel engines in order to reduce the environmentally harmful nitrogen oxides $\mathrm{NO}_{\mathbf{x}}$ emission. 


\section{References}

1. Urlaub, A. Internal Combustion Engines: Basics, Performance theory, Structure (Verbrennungsmotoren: Grundlagen, Verfahrenstheorie, Konstruktion). Berlin Heidelberg: Springer, 1995. 570 (in German)

2. Monyem A., Van Gerpen, J. H.; Canakci, M. The Effect of Timing and Oxidation on Emissions from Biodiesel-Fueled Engines. Transactions of the American Society of Agricultural Engineers (ASAE), Vol 44(1), 2001, p. 35-42.

3. Krahl, Jürgen; Munack, A.; Schröder, O.; Stein, H.; Dutz, M.; Bünger, J. Exhaust Gas Emissions and Health Effects from Biodiesel, Fossil Diesel Fuel, and Swedish Low Sulfer Diesel Fuel MKI. Paper Number: 02-6082. An ASAE Meeting Presentation. 13 p.

4. Lin, C. Y.; Huang, J. C. An oxygenating additive for improving the performance and emission characteristics of marine diesel engines. Ocean Engineering. Elsevier Science Ltd., 2003, article in press. $17 \mathrm{p}$.

5. Zvonov, V. A. The toxicity of internal combustion engines (Токсичность двигателей внутреннего сгорания). Moscow: Machinostrojenije, 1981.160 p. (in Russian).

6. Labeckas, G.; Slavinskas, S. The influence of multipurpose fuel additives on diesel engine performance. In: International conference "Mechanika-2001" proceedings (Daugiafunkcinių degalu priedy itaka dyzelinio variklio D-240 rodikliams. Tarptautinès konferencijos „Mechanika-2001“ mokslinių pranešimų medžiaga). Kaunas: Technologija, 2001 , p. 470-475 (in Lithuanian). 